JOSÉ ROBERTO DE PAIVA GOMES

PPGH / UERJ

UDC: $94: 316.343-058.12(38) “ 652$ “

Rio de Janeiro, Brasil

$304.4: 321.15(38)$ “652“"

\title{
HABROSYNE. THE CULTURAL POLITICS OF THE ARCHAIC TYRANNY
}

\begin{abstract}
In the beginning of the XIX century, on the basis of Herodotus and Thucydides, French and German researchers defined the tyranny of the Peisistratids as an overbearing, militarised government. Starting from a re-reading of Aristotle, subsequent studies from the German and Anglo-Saxon schools of thought proposed other explanatory models of the tyrant, and classified him as a bearer of mesotes (conciliator of interests) and as an aisymnetes (sage/legislator). Researchers now started looking into and formulating hypotheses bearing cultural and economic overtones. These analytical concepts brought change to the paradigms themselves, pointing that the Peisistratid government could have well presented a safe haven for the interests of the isonomy, facilitating the emergence of political and social order. From this perspective, one can argue that the Panathenaia were introduced by the tyrants with the intention of providing a sense of social well-being to the polis.
\end{abstract}

1. I. Morris (1986) and L. Kurke (1992) note that at the time of Peisistratus the tyrants paved the way for a society of adornment based upon a new mercantile oligarchy, one that acquired the power and absorbed the customs of the traditional aristocracy to affirm itself, reformulating rituals and customs from a new perspective, encompassing Ionian and Oriental habits, namely, the habrosyne. This aristocratic way of life was based on luxury, ostentation, and exaltation of Lydian habits (lydopatheia). ${ }^{1}$ The obvious evidence of this habit in the festivals can be characterised as one of the mechanisms in demonstrating the economic power of the Athenian aristocratic elite between the $\mathrm{VI}$ and $\mathrm{V}$ centuries $\mathrm{BC}{ }^{2}$

Xenokrates refers to the lydopatheia in his fr. 3, taking as example the court of the tyrant of Colophon. The poet details that he might have had about one thousand Lydian garments, usually attending the agora wrapped up in a purple mantle, with adorned hair and sprayed with fine fragrances - a costume that intensely underlines the elegance

\footnotetext{
${ }^{1} c f$. Morris 2000, 181, describing minutiae on the use of elite products.

${ }^{2} c f$. Lissarrague 1990, 240; Rosenmeyer 1992, 32.
} 
and social refinement of its owner. The lydopatheia, or, in other words, the adulation of the Lydian way of life, was showcased once again by Andrews in the 1960s, and reiterated in the linguistic studies of Drews, who redefines the word tyrannys on the basis of a poem of Archilochus (fr. 22 Diehl), in which the poet practically likens Gyges of Lydia to a great tyrant. According to Plutarch (Moralia 301 F 30a), when he rebelled against King Candaules, Gyges was supported by Carian troops. ${ }^{3}$ Drews argues that the Greek aristocrats like Cypselus in Corinth, and Peisistratus in Athens, also imitated Oriental rulers in having their own bodyguard. ${ }^{4}$ The author formulates the idea that the tyrant would be a foreigner displacing traditional aristocrats and establishing tyrannical power with the help of professional hoplites. Another perspective that Drews defends, on the basis of the studies of S. I. Oost, is that the tyrants would also be rather popular polemarchs, capable of displacing the traditional circles of aristocratic power and vesting the power onto themselves.

In his etymological analysis of the concept of habros/habrosy$n e,{ }^{5}$ Mazarino (1947) points out that aristocratic clothing was inherently linked to the context of archaic poetry - mainly in the context of the komos - as well as the relationship between the East and Greece. The emergence of the term was related to a new ideology and a noble way of life, a modus viventis articulated by the import of social values, in the context of the economic and political dynamics of the IonianLydian relationship. ${ }^{6}$

We find the term habrosyne once again in a fragment of Sappho (58 Voigt), while another contested term, habrotas appears as a hapax in Pindar (Pyth. XI.34). The sapphic instance of habrosyne appears in an extremely problematic interpretative context related to the tyranny of Pittacus: the poetess refers to the aristocracy of Mytilene, whose splendid social life is linked to freedom, leisure and the cultivation of the Beautiful. Habrosyne in Sappho is specifically related to the behaviour of the youth when presenting themselves to the public with a choir, namely, the way young aristocratic girls should behave when attending

\footnotetext{
${ }^{3}$ Herodotus (2.151-4) tells the story of Psammetichus, the founder of the Saite dynasty of Egypt, who had Carian and Ionian soldiers under his command. Furthermore, Gyges allegedly sent military reinforcements to help Psammetichus, a relationship attested on an Assyrian seal inscription (Luckenbill, 1927). This hypothesis has led Drews $(1972,129-144)$ to rethink the military theory on the establishment of tyranny, with the Eastern rulers taking power on the basis of hoplite assistance.

${ }^{4}$ cf. Mosse1969, 62.

${ }^{5}$ Solon $(18$ Gentili-Prato $=14$ D.-K.) relates the term habros to the use of wealth that grants material comfort and social well-being to the individual who possesses it; life in habrosyne encompasses food, clothing, and pleasure. Frankel $(1962,264)$, on the other hand, suggests that Solon refers to a sympotic context of a company of young men and women. In any case, the term habros is associated with the quest for well-being and comfort, one of the aspects of wealth linked to archaic aristocracy.

${ }^{6}$ viz. Starr 1977, 140.
} 
or performing in public festivals as a qualification of value; young, unmarried women were expected to demonstrate specific social attributes, such as refinement, sensibility, a pleasant appearance and social posture. Thus, the term habros gives the impression of being specifically linked to the feminine universe, mainly in the case of young women, viz. the reference of Alcaeus in fr. 42 (Voigt).

Sappho uses the word both as an adjective (habros) and an adverb (habrōs) in valuing the attributes of the youth during a ceremonial dance of the hetaireia ritual, or of the religious thiasos in Mytilene. ${ }^{7}$ Treus opines that the initial habros is related to the feminine world, its meaning being expressed in lyrical poetry as a pursuit of pleasure and refinement - one of the qualities of engaged youths - by gracious engagement in the "Music" circle of Sappho. The youths are, thus, acting out of the traditional confines of the oikos, in a social model very close to the Homeric society, where the wives of the basileis were endowed with more social freedom. It is precisely this peculiarity that opened the way for the emergence of a way of life based around the concept of habrosyne, the luxuriousness and the personal ostentation of the basileis of old, respecting, at the same time, the central role of women in social contexts of hospitality, as well as in keeping social cohesion through marriage.

2. It is generally believed that the lyrical tradition was brought to Athens in the form of the Aeolian tradition of the poets of Asia Minor. As a new commercial power in the Aegean, funded by the export of wine and olive oil, Athens made contact with the culture of lyrical poetry and the renewal of this style through the poet from Teos. According to Guia, Peisistratus and his children, Hippias and Hipparchus, were responsible for conveying a certain 'ideology of autochtony', by embracing and applying some civic conceptions of the aristocracy such as the bond to the earth and good lineage - to the whole demos, defining, in the process, the citizens and their civil laws. Peisistratus and his sons practically redefined the aristocratic ideal of Homeric times and applied it to archaic Athens. ${ }^{8}$

Plato (228-229) would have Hipparchus as the promoter of this very tradition by introducing the poetic events of the Panathenaia patroned, among others, by Anacreon and Simonides of Amorgos - as well as by widely distributing numerous hermae with poetic passages in the chora. ${ }^{9}$ We can identify the Panathenaia of the Peisistratids as a

${ }^{7}$ v. Gentili 1966, 392.

${ }^{8}$ Guia 2007,208 . According to Nagy $(1990,158)$ control over poetry was established by wealth, power and prestige. In a sense, epic poetry is oracular poetry, one to proclaim the tyrant a wise man and to ascertain his influence on the political decisions of the polis.

${ }^{9}$ In order to exercise this kind of power, the Peisistratids implemented various social transformations. Like many other tyrants, they undertook a program of public works: except works on the Acropolis, at approximately this time the temple of Dionysos was constructed, with the Agora taking a more monumental form. Another aspect of this project was the construction of water wells and springs. 
factor of social and political unification through the religious incline that served as a connection to the Homeric past and the heroic tradition of heroes like Theseus and Herakles, paving the way for the cultural synoecism $^{10}$ of the Athenians in the VI century B.C. Indeed, in Peisistratid times, the poet Anacreon - sponsored by Hipparchus - took the responsibility of transmitting the Musaic knowledge through poetry, performed before the Athenian citizenry during civic festivities. This popularisation of a sort was achieved precisely through festivities like the Panathenaia, involving prominent members of the polis, as well as women that developed a peculiar type of performance called kitharoidia, which served not only as a means to promote epic poems and values, but also to acquaint the citizens with the social norms of conduct. Furthermore, Anacreon and Simonides were brought to Athens in order to establish an air of opulent eminence - one that Kurke calls, again, habrosyne - described as a peculiar way of life established around an aristocratic circle. As a connoisseur of the culture of Oriental stamp, based on the court habits of the Lydian kingdom, what Hipparchus tried to achieve by introducing the Athenians to this concept was, in fact, to turn the citizens into loyal subjects; in the aristocratic world view, an educated man belongs to the group of the kaloi te kagathoi, those who, among other things, serve their state and ruler as well as they can.

From this we can presume that Anacreon came to Athens in order to participate in and to perform at the aristocratic symposia of Athenian society. We can observe this social practice in what we call 'Anacreontic vases" ${ }^{11}$ dated around the time of the Peisistratids, with scenes demonstrating the habrosyne through the komos and the cult to Dionysos. Athenaeus (XIII, 600) states that Anacreon received wide recognition as an animator on symposia, a lover of women, a rival of the auletai, and a virtuoso with a lyre of soft and cheerful sound. Anacreon is usually identified as a poet of love and Eros, a running theme in many a scene on Greek pottery. But he was also an ideological poet: Kurke (1992) and Morris (1996 \& 2000, 155-191) propose that the Anacreontean rhetoric be best understood as a "contest of paradigms", and its author as a representative of an elite of professional poets, whose followers would develop a cult of habrosyne, the opulent life. ${ }^{12}$

${ }^{10}$ De Romilly (1975) defines the cultic synoecism as a process of centralisation of Attic cults and gods in urban areas. In the case of the tyranny of Peisistratus, the cult of Dionysus would have been developed as part of the process of integration of social groups in both urban and rural areas.

${ }^{11}$ According to Gomes $(2010,75)$, we observe this social practice in anacreontic vessels, dating from Peisistratid times, where the aristocracy of Athens already demonstrated habrosyne through the cult of Dionysus, the performative context of komos. The male-tofemale travestic ritual was related to the transcendence of sex that Dionysus carries within himself. For a recent study on effeminising, $v$. Cerqueira 2011, 151-171.

${ }^{12}$ Aristocrats made use of the term habrosyne to indicate a diversity of interests and practices: elegance, sophistication, delicacy, comfort, well-being, and joie de vivre - specific notions that correspond to the formulation of a specific mentality in a particular social group. 
3. The concept of habrosyne may well be defined as a notion of ideological and social reality built around a group of high societal standing, one that would have easy access to luxury products coming from the East, thus transmitting a message of elegance, sophistication, comfort and pleasure. Thucydides (1.6) relates these social habits to the elder Athenian elites, but also to the Ionian society, especially in times of peace. One can also ruminate on the motivation of the potters and painters, sponsored by the tyranny in order to install the notion of the life of habrosyne in the young aristocratic minds of Athens. The adoption of habrosyne, an image of power based on displays of flashiness and luxury, comes off as a new platform for providing education to the new aristocratic (or, in any case, oligarchic) group - a new emerging elite that supports the government of the Peisistratids. It is said that, immediately after having assumed power, Peisistratus expelled several traditional noble families ${ }^{13}$ needing to insert new, emerging groups to sustain his regime through phyletic alliances with other local aristocracies, both locally and across the sea. The Peisistratids went as far as designing the musical education of youth around the kithara, as performed in the Attic festivals, wishing to establish a new form and model of attracting, motivating and manipulating marriages of noble youths with those from the emerging classes of the new mercantile aristocracy.

In due time, Athens became a pan-hellenic centre, attributing an entirely new cultural position to the texts and images of Sappho as a kithara player, teacher and educator of young women. The poems and depictions of the poetess on Attic vases would overflow the symposia as words of wisdom and an ideal model for the youth. In the public context, her poems were adapted for performing on a kithara. The textual and visual representations would be used in a sympotic context as forms of retransmission of the knowledge, facilitating a change from an oral to a written culture. ${ }^{14}$ The concept of habrosyne, however, went on to survive, admittedly under the current, as it had already taken solid root in Athenian aristocratic circles. ${ }^{15}$

Oliva observes that the emergence of the old tyranny occurred during the 7 th and the 6th centuries $\mathrm{BC}$, during a period of conflicts and disputes between the aristocracy and the demos; building on this, Reboton has the tyranny personifying not only the power of the ruler but, as a political practice, also of the state, thus playing a fundamental part in the polis concept itself. We see the regime centralising political

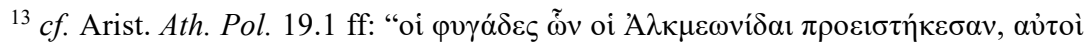

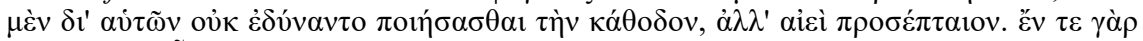

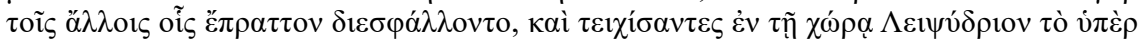

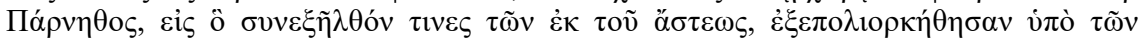

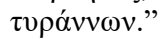

${ }^{14}$ cf. Nagy 2000; Yatromanolakis 2007, 69.

${ }^{15}$ Kurtz and Boardman 1985, 47-70; Shapiro 1981, 138-140; Hoesch 1990, 276. 
decisions, monopolising the use of force, but also providing new forms of public expression; from an institutional point of view, the tyrants would be better characterised as reformers that actually made an effort to adapt to an already existing juridical system. It is specifically through the control of the political institutions that the tyrant underlined the identity of the polis as an autonomous entity, enlivened by the emergence of state-sponsored public performances and civic festivals. Another consequence of this process was the emergence of a new social class, represented by the most illustrious members of the demos, and the emerging wealthy merchants and artisans.

This, of course, led to political struggle. In Athens itself, the struggle for power among the political factions was partly stabilised by Solon's seisatheia, establishing constitutional and legislative measures with the aim to protect the less resourceful. Such measures, however, were not sufficient to do away with the social tension; after the legislator stepped down, the battle for power duly resumed. We observe the same happening in many other places - Corinth and Miletus, for example. There, the domain of the privileged groups of aristocrats itself was threatened, culminating in their defeat in the second half of the 7th century. The less resourceful social groups, helped by the unhappy oligarchies opposing the traditional aristocracy, were now driven by the prosperity of export-oriented production and trade. The conflicts among different social groups worsened, paving the way for the rise of an individual climbing to power by military means. In agreement with Vivienne Gray's interpretation $(1995,185)$, and in spite of Herodotus not specifically underlining this particular political bond, the tyranny was intrinsically linked with military achievements. ${ }^{16}$ Ancient authors usually disseminate the idea of a presence of a certain imperialistic policy, exercised by a certain Attic/Athenian political group; Thucydides attributes this to the personal interests of the tyrant,

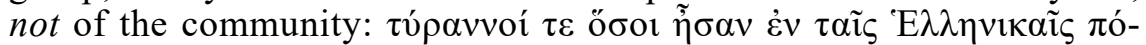

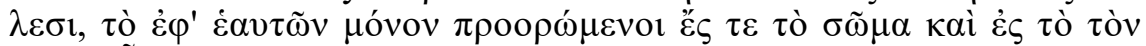

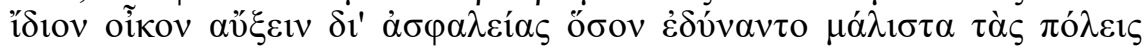

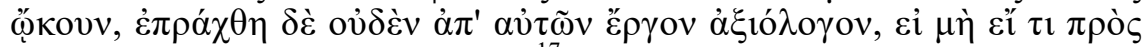

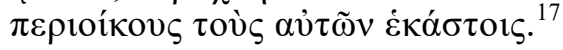

4. Following the model of Croesus, individuals that ascended to autocratic positions might have been looked upon as wise, as well; in this sense, the word itself acquired a different meaning, pointed out by Leão - one that characterises the ruler as olbios or, in other words, a

${ }^{16}$ Information provided by Herodotus and Thucydides is fundamental to the study of the tyranny of Peisistratids, as ancient authors had full access to historical accounts of his contemporaries and successors. Hermippus argues that Thucydides was related to the Peisistratids; conversely, some scholars (Grote, Ure) believed that Thucydides was informed by members of a rival family, the Philaidae.

${ }^{17}$ Thuc. 1.17. 
promoter of happiness. ${ }^{18}$ Solon and Peisistratus were indeed olbiotatoi, ultimate promoters of content citizens, generating politic dignity through prosperity. This contentment/satisfaction was strengthened by the recognition that the community was free from both internal and external dangers. What determined the continuity of the government of Peisistratus was political moderation in combination with a glorious communal life of social well-being and external safety. Despite the fact that Greek autocrats usually took the reins of the government by force in the name of personal ambition, their political attitudes and public displays went on to underline - successfully - the prosperity and the social stability of the community.

Thus, in essence, the tyranny becomes a promotor of specific societal groups, as the pioneering studies of Wachsmuth and Plass have already shown. ${ }^{19}$ More recently, the studies of Brock, Hodkinson (2000), Morgan (2003) and Lewis (2003) define tyranny as different from democracy in that it is established by a particular societal group, and supported by domestic and foreign elites. The safety of the ruler would be based on mercenary troops; however, in order for all of this to be possible, the reach for tyrannical power would have to be much more than an attempt by an individual: namely, it would need a corresponding collective attitude with a number of social groups involved.

It is from this starting point - one of accepting tyranny as a social phenomenon - that Berve proposed to give more space to the social and economic factors in the historical analyses. Berve accepts the fact that the tyrant held a fundamental political and military standing in the community; however, the stratagems of Peisistratus put aside, what should be pointed out much more vigorously is the financial help to the less resourceful, and the utilisation of military force to protect social order. This might be the reason for Grote's hoplite revolutionaries of the VII century to support a tyrant, with their sights set on breaking the political control of local aristocracies. The age of the tyrants is also an age of emerging wealth. Grote has the citizen soldiers coming from a small circle of proprietors; however, no small group would be able to make such a great political and social change in the early days of the polis, if not pushing for a generally acceptable idea that would cater to the whole populace. The hoplites pushed for societal equality by establishing conditions that would allow, for example, small and medium-sized landowners to attain political power, i.e., social conditions good enough so that anyone would be able to oppose ancient aristocracy.

Done hastily or without ideologiocal foundations, this would certainly lead to stasis. That is why, starting from the idea of the tyrant

${ }^{18} v$. Leão 2010, 81. We propose a definition of the archaic concept of olbioi related to acquisition of material goods. On the question of the Seven Sages, v. Leão 2008, 7-123.

19 For more information on the distinction in concepts between old and young tyranny, as well as the relativisation of the term "athenocentrism", v. Jordović 2005, 362. 
as a legislator, a new German line of thought defines the tyrant as an aisymnetes, linking his power with ancestral - usually heroic, most often Ionian or generally Eastern - wisdom..$^{20}$ Originally, the title of aisymnetes meant little more than a judge in sacred games; ${ }^{21}$ but soon it grew to indicate an individual voluntarily obeyed by his fellow citizens, with a practically limitless power in establishing legal norms. Aristotle in the Politics calls this "elective tyranny", 22 detaching the power of the aisymnetes from tyrannical authority. Indeed, the aisymnetes would have been named legally, but, in practice, they exercised power based on popular voluntas, not explicit laws.

This would have made Peisistratus practice economic politicies projected to bring wealth and prosperity to Athens, and Attica in general. The eunomia exercised by the tyrant may have obeyed the laws, but its true power lay in respecting justice and the freedom of the people. The tyrant would act as a wise and enlightened master, not as king. Social prosperity would be promoted by military success and the creation of colonies. The tyrant would restore peace and order through regulations and wise laws. Furthermore, at least in Athens, Peisistratus would hardly be concerned with constitutional problems like land ownership or ancestry; the tyrant preserved the Solonic order, even improving the current legal system by reducing social inequality. In this sense, the administration of Peisistratus is to be framed in the notion that archaic Greek tyranny appeared to implement laws to aid the demos. $^{23}$

5. Thus, the tyrant promoted himself as the focal point of political power, an arbiter of common interest, and, therefore, a promoter of debate for the greater public and communal Good. He would preserve the law (nomos) and justice (dike) by liberating the offices of the polis from the traditional aristocracy, maintaining the normative categories of sovereignty and common law. With societal policies losing the image of sacredness and embracing the position of a means toward the application of common group interests, the tyrant was free to treat all social issues as relevant for public debate and intellectual analysis, with his wise, enlightened self being, of course, the pillar of reflection and rational experience, not least displayed by putting habrosyne to good means.

In their more recent studies, Vernant (2007) and Mosse (2007) characterise the concept of the tyranny as an uncomfortable period of transition between aristocratic power and democracy; an intermediate period that tried to reestablish social order, but not through the notion of nomoi - laws aimed to cater to human needs - but through bie, used

${ }^{20} c f$. Lanza, 1977.

${ }^{21} v$. Berve 1967, 47; Ostwald 1969, 64-147; Raaflaub 1998, 220; Sage, 2003151.

${ }^{22}$ Arist. Pol. 3.9.5; 4.8.2.

${ }^{23}$ Going as far as trying to appoint itinerant judges in the fields, that would be promoting justice; v. Arist. Ath. Pol., 16.5; cf. Gagarin 1986, 76. 
by the tyrant to use the past, the ancestral laws, and the gods in order to reestablish order in the polis. The main political goal of the tyrant would be to neutralise the power of traditional families, building a society of more egalitarian social groups. He would assume the position of kratos, depersonalising communal contexts (especially land ownership), and distributing what he had previously appropriated. But Peisistratus never changed the constitution of Athens; in fact, Herodotus is the only ancient author that mentions replacing the patroioi nomoi with tyrannidos bie. By now, it was common knowledge that the Solonic laws were unable to achieve lasting social order in Athens, burdened by the polarisation between chora and asty; Peisistratus and his sons, in fact, tried to build upon them in order to bring balance among the social classes. Aristotle places the reasons for the discord between the aristoi and the demos; but the tyranny, in general, prospered precisely because of this agrarian crisis and the colonisation, which opened the door for the emergence of new social classes originating from peasantry and tradesmen alike. Solon might have solved the agrarian crisis for the time being by suspending the slavery of the hektemoroi, but his reforms, and particularly his sudden retreat from Athenian politics, increased factionalism and fighting among social groups. Athenian political life deteriorated to anarchy, which, following Aristotelian premises, facilitated the transition to tyranny, implanted both by political disagreements among social groups and by a lack of solid government after the legislative mandate of Solon. ${ }^{24}$ These are the political peculiarities that forced the tyrant to promote mesotes by using an unorthodox combination of mesotes and habrosyne. It is, indeed, true that mesotes and habrosyne rarely go hand in hand; except in this case, where they served to convey a clear message that an unstable society can hardly know opulence, and that habrosyne is both acceptable and possible only in well-established, socially stable state formations.

6. This line of reasoning sheds a novel light on Aristotle's claim that the old tyranny aimed to establish justice, having despotism merely as a basis of legitimacy. ${ }^{25}$ In a similar manner, several modern researchers define the reign of Peisistratus as conciliatory in character and essence, especially as compared to Solon. ${ }^{26}$ Aristotle goes as far as to describe the tyranny of Peisistratus as "the Age of Kronos", a government of rapprochement and peace. ${ }^{27}$ However, Aristotle may be the only ancient author that associates the government of the Peisistratids to the Golden Age, ${ }^{28}$ while Herodotus and Thucydides rather underline its usurpatory,

${ }^{24}$ cf. Arist. Ath. Pol., 14-15.

25 Ath. Pol. 16.8; cf. McGlew 1993, 52-86. The creation of the Guard was to be an effective mechanism against rival aristocrats. Peisistratus grabbed power as leader of the hyperakrioi, but soon after partisanship disappears, as he is benevolent to all social groups.

${ }^{26}$ V., for instance, Levecque-Naquet 1967, 39; Andrewes 1974, 108-9.

${ }^{27}$ Ath. Pol. 16.7; v. Rhodes 1981 217-8.

${ }^{28}$ cf. Zatta, 2010. 
overbearing nature. This is quite understandable, taking into account that different authors have different ideological stances and, thus, different ways of interpreting things. According to Lavalle (1993, 164), Peisistratus' main political trick was to bring about a series of measures in order to promote alliances between oligarchic families, which could have solved litigations between farmers and oligarchs, thus creating an apparent sense of justice. Lavalle would even have the myth of the Golden Age elaborated by Peisistratus as a political phenomenon - a view that may be close to the truth, as this would remove the burden of social disagreement by promoting peace, work, prosperity and abundance; thus, the tyrant becomes popular (demotikos) and benevolent (philanthropos), establishing a period of social stability, just government and prosperity, with displays of habrosyne as the logical result. Indeed, starting from $560 \mathrm{BC}$, this period of peace and prosperity is displayed in practically all artistic domains and festivals, along with heroic war themes and displays of Homeric heroes. ${ }^{29} \mathrm{Hab}-$ rosyne, which might have started as a means to convey ideological and social identity confined to a small group of well-to-do citizens, eventually grew to signify elegance, sophistication, comfort and pleasure to whomever possessed them, thus becoming a powerful political tool.

\section{SELECTED BIBLIOGRAPHY}

Andrewes, A. The Greek Tyrants, London 1956.

Andrewes, A. "The Tyranny Of Pisistratus". The Expansion Of The Greek World, Eighth To Sixth Centuries B.C. John Boardman and N. G. L. Hammond (eds)., Cambridge University Press, 1982.

Berve, H. Die Tyrannis Bei Den Griechen. Munich, 1967.

Cerqueira. F. V. As antestérias, um ritual carnavalesco de transgressão e afirmação da ordem social na antiga Atenas (sec. VI e V A.C.). UNESP - FCLAs - CEDAP, v.7, n.1, p. 151-171, jun. 2011.

De Paiva Gomes, J. R. "Os vasos anacreônticos: interações culturais entre atenienses e lídios". In Candido, M. R., Memórias do Mediterrâneo. Rio de Janeiro: NEA/UERJ, 2010, 72-80.

Drews, R. "The First Tyrants In Greece". Historia 21, 1972, 129-144.

Gagarin, M. Early Greek Law. Berkeley: 1986.

Gray, V. J. "Herodotus And The Rhetoric of Otherness" AJP 116, 1995, 185-211.

${ }^{29}$ This construction of a certain identity comprised three main elements: creating a feeling of belonging to a well-defined group, a feeling of continuity within time, and a feeling of coherence. Memory, and, thus, Homeric memory, was also a constituent element of the sense of both individual and collective identity, as an important factor in the sense of continuity and coherence of a person or a group; $c f$. Pollak 1992, 204. 
Guia, M. V. "La situacion de las mujeres en la Atenas del S. VI A. C.: Ideologia y prática de la Ciudadanía". Gerión 2007, 207-214.

Guia, M. V. "El nacimiento de la autoctonía ateniense: cultos, mitos cívicos y sociedad de la Atenas del s. VI a.C." Madrid, 2008.

Hoesch, N. "Kunst der magenerleichterung". Viemeisel, K. \& Kaiser, B. (eds.) Kunst der Schale. Kultur des Trinkens. Munich, 1990.

Jordovic, I. Anfänge der Jüngeren Tyrannis. Vorläufer und erste Repräsentanten von Gewaltherrschaft im Spaten 5. Bern / Frankfurt a.m. [U.a.]: Peter Lang, 2005.

Kurke, L. "Inventing the Hetaira: sex, politics, and discursive conflict in archaic Greece". Classical Antiquity 16.1: 1997, 106-150.

Kurtz, D. C. and John Boardman. Greek Burial Customs. London: Thames And Hudson. 1971.

Kurtz, D. C. Athenian White Lekythoi: Patterns and Painters. Oxford: Clarendon Press. 1975.

Lanza, D. Il Tiranno E Il Suo Pubblico. Turin, 1977.

Lavelle, B. M. "Herodotos, Skythian Archers, And The Doryforoi Of The Peisitratids", Klio 74, 1992, 78-97.

Lavelle, B. M. "The compleat angler: observations on the rise of Peisistratus in Herodotus (i. 59-64)", CQ 41, 1991, 317-324.

Lavelle, B. M. The Sorrow And The Pity. Franz Steiner Verlag, Stuttgart, 1993.

Lavelle, B. M. Fame, Money, and Power. The Rise of Peisistratos and 'Democratic' Tyranny at Athens. Ann Arbor: The University of Michigan Press, 2005.

Leão, D. F. et al. Cidadania e paidéia na Grécia Antiga. Coimbra: CECH, 2010.

Leão, D. F. et al. Plutarco. Obras Morais - O banquete dos Sete Sábios. Coimbra: CECH, 2008.

Leão, D. F. et al. Sólon. Ética e política Lisboa: Fundação Calouste Gulbenkian, 2001.

Levi, M. Péricles. Brasília: EdUNB, 1991.

Lissarrague, F. "Publicity and performance. Kalos inscriptions in Attic vase-painting", in: Performance, Culture and Athenian Democracy, Cambridge, 1999, 359-373.

Lissarrague, F. 'Why Satyrs Are Good to Represent', J.J. Winkler and F.I. Zeitlin (ed.), Nothing to Do with Dionysos? (Princeton and Oxford, PUPress, 1990, 228-236).

Lissarrague, F. "Dionysos S'en va-t-en Guerre", Images et Société en Grèce Ancienne. L'iconographie comme Méthode d'analyse. Lausanne, 1987, 111-120.

McGlew, J. F. Tyranny and Political Culture in Ancient Greece. Ithaca And London, 1996.

Morris, I. Archaeology as Cultural History. Words and Things in Iron Age Greece, (Malden (MA) - Oxford 2000.

Morris, I. "The Use and Abuse of Homer." Classical Antiquity 5(1986): 81-138.

Mosse, Cl. Justice et politique a Athenes. Pauline Schmitt Pantel, François de Polignac, Athènes et le politique. Dans le sillage de Claude Mossé. Paris: Éditions Albin Michel, 2007.

Nagy, G. Greek Mythology and Poetics. Ithaca, NY, 1990.

Oliva, P. “The Early Tyranny”. Dialogues d'histoire Ancienne, 1982, 8, 363-380.

Oliva, P. Solon. Legende und Wirklichkeit. Konstanz, 1982.

Osborne, R. Ancient Greece in the Making, 1200-479, London, 1996.

Ostwald, M. Nomos and the Beginnings of the Athenian Democracy. Oxford, 1969.

Podlecki, A. "Solon Or Peisistratus? A Case Of Mistaken Identity", ANCW 16 (1987), 6-7.

Rosenmeyer, P. A. The poetics of imitation. Cambridge, 1992.

Shapiro, H. A. Art And Cult Under The Tyrants in Athens. Mainz am Rhein, 1989 (1981).

Starr, Ch. G. The Economic And Social Growth Of Early Greece, 800-500 B.C. New York: Oxford University Press, 1977.

Zatta, C. "Making History Mythical: The Golden Age Of Peisistratus", Arethusa 43, 2010, 21-62. 
